\title{
ИССЛЕДОВАНИЕ НОВОГО ПУТИ ЭКОНОМИЧЕСКОГО И ТОРГОВОГО СОТРУДНИЧЕСТВА МЕЖДУ ПРОВИНЦИЕЙ ХЭЙЛУНЦЗЯН И РОССИЕЙ НА ФОНЕ СОЗДАНИЯ КИТАЙСКО-РОССИЙСКОГО МОСТА ХЭЙЛУНЦЗЯН ${ }^{1}$
}

\section{STUDY OF A NEW WAY OF ECONOMIC AND TRADE COOPERATION BETWEEN THE PROVINCE OF HEILONJIAN AND RUSSIA IN THE BACKGROUND OF THE ESTABLISHMENT OF THE CHINESE-RUSSIAN BRIDGE}

\section{Chen Zhenguang}

Summary. The article is devoted to the study of the impact of the construction of the new Heilongjiang Bridge on economic and trade cooperation between Russia and China in the Far East. In the course of the study, it was established that the functioning of this bridge will allow several times to increase the cargo and passenger traffic. Also, this element of infrastructure will have a positive effect on the dynamics of investments and the development of the regional economy of the border areas. In addition, the Heilongjiang Bridge is an important element of the New Silk Road project.

Keywords: bridge, China, Russia, economy, trade, investment.

\author{
Чэнь Чжэньгуан \\ Старший преподаватель, Хэйхэский университет \\ 1060396560@q9.com
}

Аннотация. Статья посвящена изучению влияния строительства нового моста Хэйлунцзян на экономическое и торговое сотрудничество между Россией и Китаем на Дальнем Востоке. В процессе исследования установлено, что функционирование этого моста позволит в несколько раз увеличить грузо- и пассажиропоток. Также данный элемент инфраструктуры положительно повлияет на динамику инвестиций и развитие региональной экономики приграничных территорий. Кроме того, мост Хэйлунцзян является важным элементом проекта «Новый Шелковый путь».

Ключевые слова: мост, Китай, Россия, экономика, торговля, инвестиции. овременное состояние внешнеэкономической деятельности России требует осуществления

поиска новых сегментов и ниш в мировой экономической системе и, прежде всего, в азиатском направлении, для которого характерным является огромный рынок и широкий набор различных источников инвестиций. Кроме того, реализуя данный вектор развития, Россия имеет определенные конкурентные преимущества в известных отраслях промышленности и сельского хозяйства [1].

Особую значимость внешнеэкономическое сотрудничество предприятий и регионов России в ближайшее время и на перспективу приобретает в связи с новой парадигмой развития Китая и мирового сообщества, которая находит свое проявление в рамках проекта нового «Шелкового пути» - один путь - один пояс. Одна из возможностей для экономики России в этом проекте заключена в расширении и интенсификации экономического и торгового сотрудничества с Китайской народной республикой не только в пределах уже известных сегментов и отраслей, но и в направлении создания принципиально новых плоскостей приложения совместных усилий.

На 25-й очередной встрече премьер-министров Китая и России, состоявшейся в декабре 2020 года, в совместном коммюнике было указано на всестороннее содействие скорейшей реализации проекта по открытию китайско-российского моста Хэйлунцзян. После

1 Данная статья публикуется в рамках научно-исследовательского проекта основного операционного расхода вузов провинции Хэйлунцзян 2019 г. на тему «Исследование нового пути экономического и торгового сотрудничества между провинцей Хэйлунцзян и Россией на фоне создания китайского-российского моста Хэйлунцзян». Проект 2019-KYYWF-0457 
завершения строительства моста Хэйлунцзян люди из двух мест смогут добраться до противоположного берега всего за 6 минут в одну сторону. Этот проект является воплощением непрерывного ускорения строительства трансграничных транспортных объектов между Китаем и Россией. Согласно проектному плану дорога через Хэйлунцзян имеет общую протяженность 973 метра и включает 4 нитки.

После ввода проекта в эксплуатацию значительный импульс развития получат транспортные и логистические потоки, кроме того, мост позволит снизить нагрузку на портовые перевозки, значительно повысить эффективность оформления пассажиров, будет способствовать объединению транспортной инфраструктуры обеих сторон. Не подлежит сомнению тот факт, что строительство китайско-российского моста Хэйлунцзян поможет двусторонним торгово-экономическим обменам стать более удобными и беспроблемными.

Таким образом, указанные обстоятельства предопределяют выбор темы данной статьи, а также подтверждают ее актуальность, теоретическую и практическую значимость.

Перспективы наращивания трансграничного взаимодействия Китая и России, в частности, благодаря строительству моста «Амур (Хэйлунцзян)» рассматривают в своих трудах такие авторы как: Laisi, M.; Hilmola, O.P.; Sutela, M.; Nekhoroshkov, V.P.; Xiaoyan, L.; Malle, Silvana; Bennett, Mia M.

Вопросами углубления международного разделения труда и международной экономической кооперации благодаря развитию и расширению транспортных коридоров между Россией и Китаем занимаются Москвитина Н.Г., Подойницына И.И., Ма Ю., Суслов Д.В., Diesen, Glenn; Jung, Hyunjae; Kim, Jaewon; Shin, KwangSup.

Исследования, касающиеся комплексного решения проблем повышения эффективности развития транспортной системы приграничных территорий Дальнего Востока России и провинции Хэйлунцзян через призму экономического и торгового сотрудничества, гуманитарных обменов и развития инфраструктуры были выполнены Линлин В., Жу Ц., Чжоу Я., Яо Яо., Песцовым С.К., Волынчуком А.Б., Yun, Y.; Park, K.; Chuai, Xiaowei; Lu, Qinli; Huang, Xianjin; Gao, Runyi.

В тоже время, необходимо отметить, что в большинстве имеющихся на сегодняшний день научных работ перспективы развития транспортного сообщения между Дальним Востоком России и провинцией Хэйлунцзян рассматриваются с позиций оптимизации логистических процессов, перевозок и развития международных коридоров. Однако ключевым вопросам стимулирования экспорта товаров, развития торгово-экономических отношений между приграничными территориями не уделено должного внимания.

Учитывая вышеизложенное, цель статьи заключается в изучении перспектив экономического и торгового сотрудничества между провинцией Хэйлунцзян и Россией с учетом создания китайско-российского моста Хэйлунцзян.

Китайско-российский мост Хэйлунцзян относится к отрасли строительства дорог и мостов и играет определенную роль в развитии многих промышленных секторов. Оценку его экономического воздействия можно разделить на оценку краткосрочного экономического эффекта и оценку долгосрочного экономического эффекта. Краткосрочный экономический эффект в основном относится к экономическому эффекту в период строительства, а долгосрочный экономический эффект связан с получением выгод и преимуществ в период его эксплуатации.

Результаты анализа показывают, что мост Хэйлунцзян играет наиболее важную роль в развитии промышленности и энергетики в период строительства и ввода в эксплуатацию. Это в основном связано с тем, что строительная отрасль относится к числу основных в национальной экономике как России, так и КНР. В период эксплуатации мост Хэйлунцзян позволит увеличить объем перевозок по маршруту за счет снижения транспортных расходов. С учетом особого расположения моста главное его влияние найдет свое проявление в увеличении объемов торговли. В течение долгого времени Китай экспортировал текстиль и переработанную сельскохозяйственную продукцию в Россию через порт Хэйхэ, а Россия экспортировала продукцию машиностроения и энергию в Китай. Завершение строительства китайско-российского моста Хэйлунцзян еще больше расширит масштабы и методы торговли в порту.

Рассмотрим более подробно конкретные долгосрочные экономические эффекты.

Итак, мост Хэйлунцзян является неотъемлемым элементом зоны свободной торговли Хэйлунцзян, которая была создана в 2019 году и охватывает районы Харбина, Хэйхэ и Суйфэньхэ. Последние два района расположены в приграничной зоне между Китаем и Россией. Уникальное географическое положение зоны свободной торговли Хэйлунцзян и тесные контакты с Россией в контексте открывшихся транспортных возможностей позволят привлечь больше компаний из обеих стран. Строительство и дальнейшее развитие транспортной 
инфраструктуры в рамках зоны свободной торговли предоставит предприятиям РФ и КНР новые возможности для укрепления сотрудничества, а также будет способствовать развитию взаимовыгодных связей между Россией и Китаем в области науки и технологий, сельского хозяйства, финансов и торговли.

В 2018 году объем торговли между Россией и Китаем превысил 100 миллиардов долларов США и логистика имеет жизненно важное значение для реализации инвестиционных проектов, поскольку она позволяет снизить затраты и сделать проект прибыльным. Этот мост открывает новые возможности для инвестиций на Дальнем Востоке и развития экономики России. Согласно расчетам, каждые сутки по мосту смогут проезжать 164 автобуса, 630 грузовых автомобилей, 68 легковых машин и около 5,5 тысячи человек. Для организации такого потока с нуля строится двадцать километров подъездных путей: 13,4 километра по российской территории и 6,7 - по китайской. Опираясь на мост Хэйлунцзян, Россия планирует построить транспортные, логистические комплексы и туристические объекты, а также реализовать больше проектов сотрудничества с Китаем для ускорения развития. Все это в целом позволит устранить логистические ограничения при экспорте товаров и будет способствовать строительству (модернизации) пунктов пропуска через государственную границу.

По прогнозам экспертов, к началу эксплуатации моста годовой пассажиропоток может составить 1,4 миллиона пассажиров, а грузовой - достигнет 3 млн. тонн, к 2035 году ожидается 6,2 млн. тонн и 3 млн. человек. Такие города на северо-востоке, как Харбин, Чанчунь и Суйфэньхэ, создают комплексные пилотные зоны для трансграничной электронной торговли, а соответствующая политика преференций будет способствовать развитию трансграничного сотрудничества в области электронной торговли между Китаем и Россией.

Особое внимание необходимо уделить тому факту, что мост Хэйлунцзян позволит снизить нагрузку на порт Хэйхэ, о котором уже упоминалось ранее, и который имеет самую высокую пропускную способность на китайско-российской границе. Однако его функционирование ограничено периодом весеннего и осеннего дрейфа льда в Хэйлунцзяне, в результате эффективное время перевозки грузов в порту Хэйхэ составляет всего около 240 дней в году. Расширение и развитие новой инфраструктуры даст возможность снизить зависимость торговли и перевозок между Россией и Китаем от климатических условий.

Также мост Хэйлунцзян важен с точки зрения развития автотуризма между двумя странами. В данном плане власти России поставили очень амбициозную задачу - обеспечить, чтоб не менее двух миллионов человек в год пересекали границу по мосту Благовещенск - Хэйхэ.

Помимо этого, следует сделать акцент на том, что мост Хэйлунцзян имеет решающее значение не только с точки зрения соединения двух приграничных регионов России и Китая, благодаря ему будет сформирована новая международная автомагистраль, которая обеспечит прямое соединение двух городов на уровне префектур в Китае и России и добавит важную трансграничную инфраструктуру для строительства «Нового Шелкового пути» Китай-Монголия-Россия. После полного введения моста Хэйлунцзян в эксплуатацию Китай и Россия войдут в стадию строительства вспомогательных объектов, опираясь на международную секцию совместного управления моста Хэйлунцзян для создания зоны приграничного экономического сотрудничества и дальнейшего развития взаимосвязи инфраструктуры между китайской провинцией Хэйлунцзян и Дальним Востоком России.

Таким образом, анализ влияния строительства моста Хэйлунцзян на экономические между Россией и Китаем, свидетельствует о том, что он позволит интенсифицировать динамику и улучшить структуру торговли, расширить инвестиции и сократить логистические затраты.

\section{ЛИТЕРАТУРА}

1. Hooijmaaijers, Bas China, the BRICS, and the limitations of reshaping global economic governance // The Pacific review. 2021. Volume 34: Number 1; pp 29-55.

2. Chuai, Xiaowei China's construction industry-linked economy-resources-environment flow in international trade // Journal of cleaner production. 2021. Volume 278; pp 13-19.

3. Offering a Different Choice The China-Russia relationship's contribution // Beijing review: a Chinese weekly of news and views. 2019. Volume 62: Number 28; pp 24-29. 